解 説

[環境化学 (Joumal of Environmental Chemistry) Vol. 3, No. 2, pp. 295-304, 1993]

\title{
環境化学分野における光化学反応の利用
}

\author{
石川 精一・末冨 良次 \\ 北九州市環境衛生研究所 \\ （ ₹804 北九州市戸畑区新池1-2-1）
}

[平成 5 年 2 月 4 日受理］

\section{Utilization of Photochemical Reaction in Environmental Chemistry}

\author{
Seiichi ISHIKAWA and Ryoji SUETOMI \\ Kitakyushu Municipal Institute of \\ Environmental Health Sciences \\ (1-2-1 Shinike, Tobata-ku, Kitakyushu 804)
}

[Received February, 4 , 1993]

\section{1.はじめに}

環境庁, 厚生省, 通商産業省を中心とした化学物質に 関する総合調查がわが国で実施されて 20 年が経過した が, その調查・研究の成果として, 化学物質が種々の規 制項目に追加されつつある。規制項目の増加はそれらの 分析を担当する地方衛生公害研究所にとって苦労の多い ところであるが, 浄水処理や廃水処理に携わっている者 にとっても，新たに定められた基準の達成のために，高 度水処理の導入等による削滅対策に苦心していることと 察する。

化学物質に対する水処理方法としては, 活性炭処理が 一般的であるが，近年紫外線やオゾンを用いた方法に関 する報告も増加している。特に, 現在問題となっている 有機ハロゲン化合物やニトロ化合物, 農薬等の処理にお いて, 紫外線照射处理が効力を示すという報告は多く, 今後水処理に限らず, 環境化学分野全般にわたって, 光 化学反応の利用が考えられる。そこで, 光化学反応に取 り組む際の参考としていただくため, 光化学反応の基礎 的原理や反応装置, 有機光化学反応例について触れると ともに, 環境化学分野における最近の研究報告例を紹介 する。

\section{2. 光化学反応の歴史的背景}

有機光化学反応について, 研究らしい研究が行われ始 めたのは今世紀になってからで，1900年から1920年にか
けて, イタリアの G. Ciamician とドイツのP. Silber は数 十報の報告を出している。しかし, 当時の光源は太陽光 で実用的な紫外線ランプが得られなかったことや光化学 反応生成物の構造を決定する手段がなかったことなどか ら, 有機化学者による研究に一旦休止符が打たれ, 一転 して物理化学者の手による光化学反応の基礎的な研究の 時代となった。M. Planckや A. Einsteinによって確立さ れた光量子理論を背景として, 多くの物理化学者によっ て現在の光化学の基礎となる発見がなされた。一方, 研 究手段の進歩とともに1950年前後から再び有機化学者が 光化学分野に進出し, A. Schonberg や G. O. Schenck, D. H. R. Barton, G. S. Hammond らが合成的, 機構的な研究 に重要な発見をして以来, 急速な発展をたどっている11。 環境化学分野において, 光化学反応が注目され始めた のは将に公害問題の勃発時からで, オゾン層での光化学 反応や光化学オキシダントの発生, PCBの分解などを 始めとして, 種々の研究が現在までになされてきた。研 究の手本は今までの有機化学分野における有機合成的な 報告ではあるが, 有機合成では有機溶媒中で反応が行わ れる場合が多いのに対し, 環境化学の分野では水相や気 相で行われ, 対象となる物質も異なることが多いため, そのまま参考にできるものは少ない。また, 詳細な反応 生成物についての同定や反応機構の解明もなされていな い場合が多く, 環境化学分野における光化学研究は今後 の課題である。 


\section{3. 光化学反応}

\section{1 雪磁波の性質と物質への作用堣橉}

電磁波はその光源と必要な検出器によって表 $1^{2)}$ のよ うに分類される。1 光子のエネルギー $\varepsilon(\mathrm{J})$ は $\varepsilon=\mathrm{h} \nu$ $=\mathrm{hc} / \lambda （ \mathrm{~h}$ ：プランク定数 $6.626 \times 10^{-34} \mathrm{Js}, \nu$ ：振動 数 $\mathrm{s}^{-1}, \mathrm{c}$ : 光速度 $3 \times 10^{8} \mathrm{~ms}^{-1}, \lambda:$ 波長 $\left.\mathrm{m}\right)$, モルエ ネルギーは $6.02 \times 10^{23} \mathrm{~h}$ レでそれぞれの波長を持つ電磁 波では，表 1 に示したエネルギー値を与える。

電磁波の物質への作用機構を考える場合, 分子軌道の 概念が当てはめられる ${ }^{3)}$ 。例えば, 紫外線を有機分子に 当てると，光子を吸収した有機分子では，結合性軌道に ある電子が反結合性軌道に励起される。この与えられた 励起エネルギーは内部交換や交換交差, 蛍光, リン光に よって放出されるが, さらに紫外線を当て続けると, 結 合性軌道にあった電子対が反結合性軌道に移るため, 分 子内結合の解離が起こる。解離の容易さは分子内の結合 エネルギーの大きさによる。すなわち, モルエネルギー が598kJ・ mol-1の紫外線は表 $2^{4)}$ に示すようにほとんど の一重結合の解離の可能性を示し, 二重, 三重結合にお いても $\pi$ 電子軌道に作用する。このような作用機構のた め, 通常の化学的分解や生分解では大きく影響する原子 団の性質や立体障害の影響は結合の切断時点においては ほとんど関係なく，また切断も各部分で同時に起こり得
る。こうした特徴が環境において難分解性で毒性を持つ 化合物の分解や無害化を引き起こす。環境化学分野で最 も問題となる $\mathrm{C}-\mathrm{X}\left(\mathrm{X}\right.$ ：ハロゲン原子) 結合や $\mathrm{C}-\mathrm{NO}_{2}$ 結合を含む化合物は紫外線照射によって容易にその結合 部の切断を起こし, それぞれ無害の $\mathrm{X}^{-}$イオンや $\mathrm{NO}_{3}{ }^{-}$ イオンを生じる ${ }^{5-7)}$ 。 $\mathrm{C}-\mathrm{NH}_{2}$ 結合も光酸化後切断が起 こり $\mathrm{NO}_{3}$-イオンを生じる5,6)

\section{2 光化学反応装置 $8-10$ )}

(1) 光源

環境中で起こる光化学反応は太陽光によるものであ り, そのため太陽光を用いた光分解試験はよく行われる が, 環境中で起こる光化学反応や藻類の増殖を早めたり, 物質の処理を目的とする場合, 種々の光源が用いられる。 a. 水銀ランプ

水銀の不連続なスペクトル線を利用するもので, ラン プ内に封入されている水銀の蒸気圧により強度分布比が 異なり, 低圧 $\left(10^{-3} \sim 1 \mathrm{mmHg}\right)$, 中圧 $(1 \sim 35 \mathrm{mmHg})$, 高圧 ( $1 \sim 100 \mathrm{~atm})$, 超高圧 (100 300atm) に大別さ れる。

低圧水銀ランプは $253.7 \mathrm{~nm}$ のスペクトル線に約 $90 \%$ の エネルギーが集中しており，この領域に吸収がある化合 物の光反応や水銀増感反応に用いられる。また, 殺菌効 果が大きい。このランプには熱陽極型と冷陽極型があり,

表 1 電磁波の分類

\begin{tabular}{|c|c|c|c|c|c|c|c|c|c|c|}
\hline & 真空中での & & $\begin{array}{l}\text { 真空中での } \\
\text { 波数 }\end{array}$ & & \multicolumn{2}{|l|}{ 振動数 } & \multicolumn{2}{|c|}{ 光子エネルキー } & \multicolumn{2}{|c|}{ モルエネルキー } \\
\hline$r$ 線 & 10 & $\mathrm{pm}$ & $10^{\circ}$ & $\mathrm{cm}^{-1}$ & 30.0 & $\mathrm{EHz}$ & $19.9 \times 10^{-15}$ & $\mathrm{~J}$ & 12.0 & $\mathrm{GJ} \cdot \mathrm{mol}^{-1}$ \\
\hline X 儤 & 10 & $\mathrm{~nm}$ & $10^{8}$ & $\mathrm{~cm}^{-1}$ & 30.0 & $\mathrm{PHz}$ & 19. $9 \times 10^{-18}$ & $\mathrm{~J}$ & 12.0 & $\mathrm{MJ} \cdot \mathrm{mol}^{-1}$ \\
\hline & 200 & $\mathrm{~nm}$ & $50.0 \times 10^{3}$ & $\mathrm{~cm}^{-1}$ & 1.50 & $\mathrm{PHz}$ & $993 \times 10^{-21}$ & $\mathrm{~J}$ & 598 & $\mathrm{~kJ} \cdot \mathrm{mol}^{-1}$ \\
\hline & 380 & $\mathrm{~nm}$ & $26.3 \times 10^{3}$ & $\mathrm{~cm}^{-1}$ & 789 & $\mathrm{THz}$ & $523 \times 10^{-21}$ & $\mathrm{~J}$ & 315 & $\mathrm{~kJ} \cdot \mathrm{mol}^{-1}$ \\
\hline 土从 & 780 & $\mathrm{~nm}$ & $12.8 \times 10^{3}$ & $\mathrm{~cm}^{-1}$ & 384 & $\mathrm{THz}$ & $255 \times 10^{-21}$ & $\mathrm{~J}$ & 153 & $\mathrm{~kJ} \cdot \mathrm{mol}^{-1}$ \\
\hline & 2.5 & $\mu \mathrm{m}$ & $4.00 \times 10^{3}$ & $\mathrm{~cm}^{-1}$ & 120 & $\mathrm{THz}$ & $79.5 \times 10^{-21}$ & J & 47.9 & $\mathrm{~kJ} \cdot \mathrm{mol}^{-1}$ \\
\hline & 50 & $\mu \mathrm{m}$ & 200 & $\mathrm{~cm}^{-1}$ & 6.00 & $\mathrm{THz}$ & 3. $98 \times 10^{-21}$ & $\mathrm{~J}$ & 2. 40 & $\mathrm{~kJ} \cdot \mathrm{mol}^{-1}$ \\
\hline & 1 & $\mathrm{~mm}$ & 10 & $\mathrm{~cm}^{-1}$ & 300 & $\mathrm{GHz}$ & $199 \times 10^{-24}$ & $\mathrm{~J}$ & 120 & $\mathrm{~J} \cdot \mathrm{mol}^{-1}$ \\
\hline ラシ・オ波 & 100 & $\mathrm{~mm}$ & 0.1 & $\mathrm{~cm}^{-1}$ & 3.00 & $\mathrm{GHz}$ & $1.99 \times 10^{-24}$ & $\mathrm{~J}$ & 12.0 & $\mathrm{~J} \cdot \mathrm{mol}^{-1}$ \\
\hline
\end{tabular}


表 2 結合エネルギー

\begin{tabular}{|c|c|c|c|c|c|}
\hline $\mathrm{H}-\mathrm{H}$ & 436.0 & C $1-\mathrm{H}$ & 431.4 & $C-F$ & 485 \\
\hline$F-F$ & 157 & $\mathrm{~B} \mathrm{r}-\mathrm{H}$ & 366 & $\mathrm{C}-\mathrm{C} 1$ & 335 \\
\hline $\mathrm{C} 1-\mathrm{C} 1$ & 242 & $\mathrm{I}-\mathrm{H}$ & 299 & $\mathrm{C}-\mathrm{Br}$ & 285 \\
\hline $\mathrm{Br}-\mathrm{Br}$ & 193 & $\mathrm{C}-\mathrm{H}$ (メタン $)$ & 416 & $\mathrm{C}-\mathrm{I}$ & 218 \\
\hline$I-I$ & 151 & $\mathrm{C}($ 脂肪族 $)-\mathrm{H}$ & 412 & $\mathrm{C}-\mathrm{O}$ & 356 \\
\hline$O=0$ & 493 & $=\mathrm{C}-\mathrm{H}$ & 425.1 & $\mathrm{C}=\mathrm{O}$ (アルデヒド) & 736 \\
\hline $\mathrm{N}-\mathrm{N}$ & 217 & $\equiv \mathrm{C}-\mathrm{H}$ & 432.6 & $\mathrm{C}=\mathrm{O}$ (ケトン) & 749 \\
\hline $\mathrm{N}=\mathrm{N}$ & 376 & C - C (黒鉛) & 715.1 & $\mathrm{C}-\mathrm{N}$ & 305 \\
\hline $\mathrm{N} \equiv \mathrm{N}$ & 945.2 & $\mathrm{C}-\mathrm{C}$ (ダ 价於 $)$ & 355 & $C=N$ & 615 \\
\hline $\mathrm{N}-\mathrm{H}$ & 391 & $C-C$ & 347 & $\mathrm{C} \equiv \mathrm{N}$ & 891 \\
\hline $\mathrm{O}-\mathrm{H}$ & 462.3 & $C=C$ & 610.0 & & \\
\hline $\mathrm{F}-\mathrm{O}$ & 565 & $\mathrm{C} \equiv \mathrm{C}$ & 835.1 & & \\
\hline
\end{tabular}

$\left(\mathrm{kJ} \cdot \mathrm{mol}^{-1}, 25^{\circ} \mathrm{C}\right)$

前者は本質的には蛍光灯と同じで，封入管が石英や Vycor で，蛍光物質を塗着していない点が異なる。市 販の低圧水銀ランプの大部分はこの型であり，比較的低 電圧 $(100 \mathrm{~V}, 10 \sim 40 \mathrm{~W})$ である。

中圧及び高圧水銀ランプは 200 - 600nm の幅広いスぺ クトルを与え, 輝度も高いので有機光化学反応に最も多 く用いられる。市販のランプは100〜1000W のものが多 い。著者らの実験では ${ }^{11)}$, 数十種類の芳香族有機塩素 化合物に対して，低圧水銀ランプ（15W）を用いた場合 も高圧水銀ランプ (100W) を用いた場合も分解速度は あまり変わらなかったので，化合物の分解を目的とする 場合は低圧水銀ランプの方が低電力ですむ。

超高圧水銀ランプは可視光領域ではほとんど連続的な スペクトルを与え, 輝度の高い平行光線が得られるため, ESR や NMR に用いられる。

\section{b. 可視領域の光を与える光源}

太陽光は310nm 以下の光は遮断することができ， $480 \mathrm{~nm}$ 付近に最大強度を持つ良い可視光源であるが，実 験的には白熱電球や高圧水銀ランプ, タングステンーハ ロゲンランプ, キセノンランプ, 水銀一キセノンランプ が用いられる。

タングステンーハロゲンランプは紫外領域の光をほと んど出さず，小型で高輝度（10１500W）, 長寿命であ るが, 赤外部の放射も多いので冷却する必要がある。特 に，色素増感反応には適している。

キセノンランプは可視領域で連続的なスペクトルを与
える。紫外及び可視両領域の光を必要とする場合には水 銀一キセノンランプが用いられる。

強力な光を瞬時必要とする場合, 閃光ランプやレー ザーが用いられる。レーザーは極めて狭い波長幅（1 $6.00 \AA$ A ) で, 強力な出力を可視及び紫外領域で与える。

\section{(2) フィルター}

光化学反応の機構の研究には単色光を必要とする。単 色光を得るためには，プリズムや回折格子を用いたモ） クロメーターが市販されているが, モノクロメーターで 得られた光では光強度が弱すぎるので, ガラスフィル ターや化学フィルターが用いられる。図 1 に各種のガラ スの各波長における透過率を示した。狭い波長幅の単色

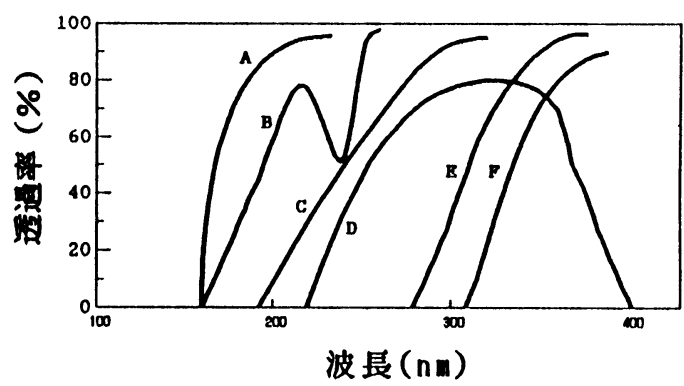

図 1 各種のガラス材料の光透過率

A: Suprasil $(10 \mathrm{~mm})$, B: 石英 $(10 \mathrm{~mm})$, C: Vycor No. 791 (1mm), D: Corning 9863 (No.7-54)(3mm), E: 化学用 Pyrex, F: 空ガラス $(2 \mathrm{~mm})$ 
A

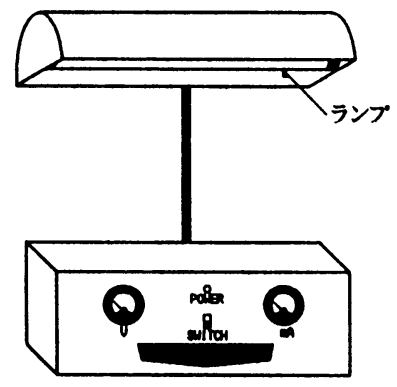

C

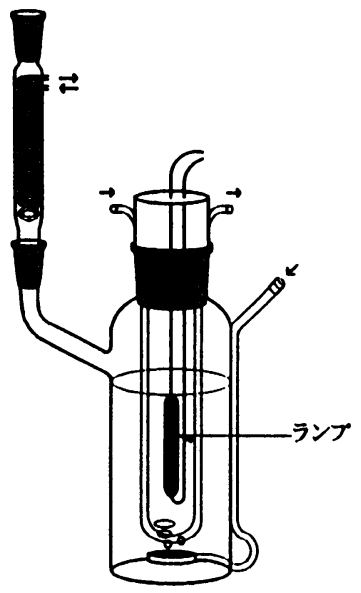

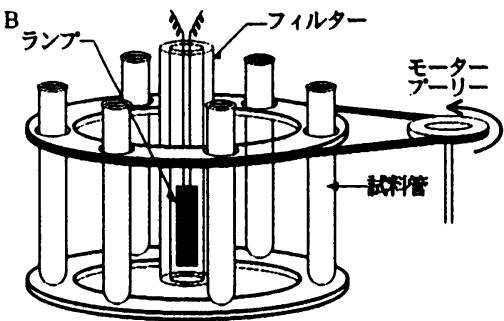

D

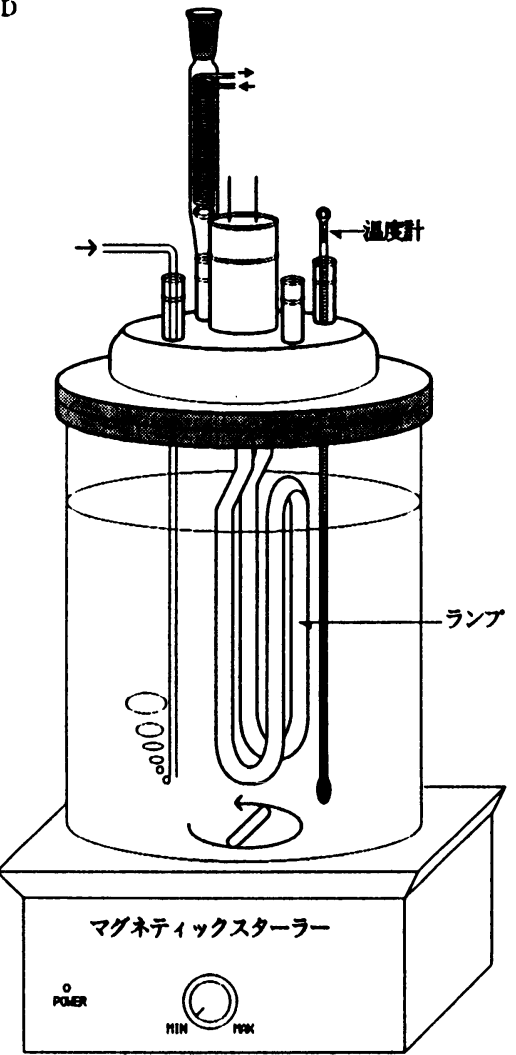

図 2 光化学反応装置

$A$ : 外部照射型,

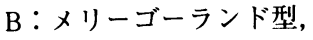

C, D：内部照射型

光を取り出すためには, 化学フィルターとガラスフィル ターまたは干渉フィルターを組み合わせる。

（3）反応槽及び装置（図 2 ）

外部照射型と内部照射型に大別され，外部照射型のも のは効率良く光を吸収させるよう反応槽の形状の工夫が 必要である。メリーゴーラウンド型のものは多数の反応
系について同時に同じ条件で照射できるので量子収率の 測定や消光の動力学試験を行うときに用いられる。環境 化学分野においては, 化合物の分解速度の比較などに利 用できるが, 反応槽の容量が小さいので希薄溶液の場合 は化合物の測定が困難な場合がある。

内部照射型は光が効率良く試料溶液を透過でき, 反応 
槽の容量も比較的大きくできるので, 多くの有機合成反 応や光分解の経時変化,生成物の同定などに利用できる。 フィルターを必要とする場合はランプの回りに円筒型の ガラスフィルターを挿入したり, 化学フィルターの場合 は溶液がランプを囲むような構造にする。発生ガスの捕 集やガスの導入, 加熱, 摚找ができるものも市販されて いるが, 環境化学分野で利用する場合はさらに様々な工 夫が必要である。

\section{(4) その他}

光化学実験を行う場合, 光の強度や量子収率を測定し ておく必要がある。環境化学分野においては，太陽光に 換算する場合や化合物の分解挙動に定量性を持たせるた め不可欠である。 3 波長での光強度を測れるものが市販 されており, また実際の溶液での量子収率を求める時は, トリオキサラト鉄（III）カリウムやシュウ酸ウラニルな どを用いた化学光量計を利用する。

ランプからの紫外線に目や皮虙を曝さないようサング ラスや手袋を着用し, 反応装置は暗幕やアルミホイルで 覆い光を遮断する。 $260 \mathrm{~nm}$ 以下の強い光を放射するもの はすべてオゾンを発生するので，換気に注意する。高圧 及び超高圧水銀ランプは数百 Vで使用するので注意を する。可燃性のものや爆発性のものを使用するときは, 冷却や取扱いに注意する。

\section{3 有业光化学反応例 $1,9,10)$}

有機化学の分野では, 光還元, 光酸化, 光付加, 光二 量化, 光環化, 光転位, 光異性化, 光加溶媒分解, 光脱 離, 光開環, 光置換反応などが知られている。環境化学 の分野においては, 反応が強極性の水相や気相で行われ, 濃度レベルも ppm 以下と希薄であり, さらに種々のマ トリックスを含むことが多いため，そのまま適用するこ とはできないが，研究を進めて行く上で参考になるの で, 環境化学分野に関連があると思われる反応例を示す。 （1）カルボニル化合物の光還元

光励起カルボニル化合物は水素供与体 $\mathrm{R} \mathrm{H}$ (アミン類, アルコール類, 炭化水素類, フェノール類, アミド類な ど）の存在下で, R H から水素引き抜き反応を行い, ヒ ドロキシメチル基と $\mathrm{R}$ ・ラジカルを与える。最終反応生 成物は生成したラジカルの二量化や交差結合により生成 される。

$$
\mathrm{R}_{2}{ }_{2} \mathrm{C}=\mathrm{O}+\mathrm{RH} \rightarrow \mathrm{R}_{2}{ }_{2} \mathrm{COH}+\mathrm{R} \cdot
$$

水素引き抜き段階の効率は, カルボニル化合物の三重 項状態の第一励起状態の性質や構造, $\mathrm{R}-\mathrm{H}$ 結合の解離 エネルギー, 溶媒の型に支配される。従って, イソプロ ピルアルコール中では, アセトフェノン, ベンゾフェノ ン, アセトンは容易に光還元されるが, 1-ナフトアルデ ヒド，2-アセトナフトン, $\mathrm{p}-$ フェニルベンゾフェノン
は反応しない。しかし， $\mathrm{R}-\mathrm{H}$ 結合の解離エネルギーが 低ければ（例えばトリブチルスズなど）光還元される。

$\mathrm{p}$-アミノベンゾフェノンのように $\mathrm{p}$-位に強い電子供 与性基がある場合, カルボニル基へ電荷移動をもたらし, 励起状態において次の構造をもたらす。この構造は極性 溶媒中で安定化され, 酸素原子上の負電荷は水素引き抜 きを阻害し，光還元は起こらない。

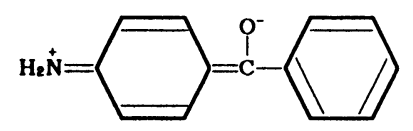

その他，o-置換されたアルキルベンゾフェノン類で六 員環遷移状態を形成し得る場合には, 分子内水素引き抜 きを起こすことができる。

\section{(2) 光酸化}

有機化合物を増感剤と酸素の存在下で光照射すると, 酸化生成物を与える。反応は増感剤の存在が不可欠であ り, 基質から水素を引き抜いてラジカルを生成し，つい で酸素と反応する I 型過程と酸素を活性化して酸素と 基質間の直接的な反応を起こさせる II 型過程で起こ る。

\section{$<$ I 型過程 $>$}

$$
\begin{aligned}
& \text { sens }+\mathrm{h} \nu \rightarrow \operatorname{sens}\left(\mathrm{S}_{1}\right) \rightarrow \operatorname{sens}\left(\mathrm{T}_{1}\right) \\
& \text { sens }\left(\mathrm{T}_{1}\right)+\mathrm{RH} \rightarrow \cdot \text { sens }-\mathrm{H}+\mathrm{R} \cdot \\
& \mathrm{R} \cdot+\mathrm{O}_{2} \rightarrow \mathrm{RO}_{2} \cdot \\
& \mathrm{RO}_{2} \cdot+\mathrm{RH} \rightarrow \mathrm{ROOH}+\mathrm{R} \cdot \\
& \mathrm{RO}_{2} \cdot+\cdot \text { sens }-\mathrm{H} \rightarrow \mathrm{ROOH}+\text { sens }
\end{aligned}
$$

$<$ II 型過程 $>$

(a) sens $+\mathrm{h} \nu \rightarrow \operatorname{sens}\left(\mathrm{S}_{1}\right) \rightarrow \operatorname{sens}\left(\mathrm{T}_{1}\right)$ sens $\left(\mathrm{T}_{1}\right)+\mathrm{O}_{2} \rightarrow \cdot$ sens $-\mathrm{O}-\mathrm{O} \cdot$ - sens $-\mathrm{O}-\mathrm{O} \cdot+\mathrm{M} \rightarrow$ sens $+\mathrm{MO}_{2}$

(b) sens $+\mathrm{h} \nu \rightarrow \operatorname{sens}\left(\mathrm{S}_{1}\right) \rightarrow \operatorname{sens}\left(\mathrm{T}_{1}\right)$ $\operatorname{sens}\left(\mathrm{T}_{1}\right)+\mathrm{O}_{2} \rightarrow$ sens $+\mathrm{O}_{2}\left(\mathrm{~S}_{1}\right)$ $\mathrm{O}_{2}\left(\mathrm{~S}_{1}\right)+\mathrm{M} \rightarrow \mathrm{MO}_{2}$

( 3 ) 光付加

光付加とは, 電子的励起分子が別種の基底状態分子と 結合して, $1: 1$ の光付加物を与えることを意味し, オ レフィンの混合物を光照射するとき，ごく普通に起こる ことである。キノン, アルデヒド, ケトン, オレフィン, 芳香族炭化水素の混合二分子付加が知られている。

カルボニルーオレフィン系の場合, 光励起したカルボ ニルのオレフィンへの求電子攻撃が起こり, オキセタン 構造が造られる。<smiles>CC(=O)[C-](C)C(C)=C(C)C</smiles> 
ベンゼン環への光付加は, 1,2-, 1,3-あるいは 1,4付加が起こり得るが, 1,2-付加が最も多い。ベンゼンと マレインイミド間の反応は次のように起こり，付加物は 三重項増感剂の有無にかかわらず生成し，酸素は増感反 応においては付加物生成を阻害するが, 非増感反応では 阻害しない。また, ベンゼンは単環式芳香環系とは 1 ： 2 付加物を形成するが, 多環式芳香族炭化水素とは 1 : 1 付加物のみができる。

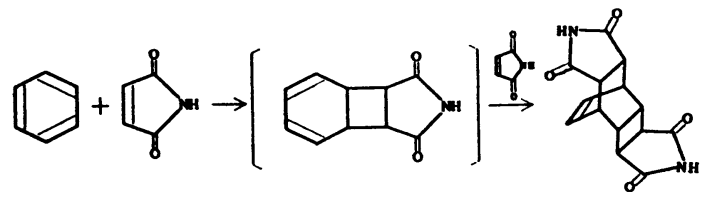

(4) 光二量化

光二量化とは, 電子的励起分子が同種の基底状態分子 と結合して，1：1の光付加物を与えることを意味し， 多くの芳香族炭化水素やモノオレフィン, 共役ジエン, $\alpha, \beta$-不飽和カルボニル化合物について, 光二量化が 起こることが知られている。オレフィン化合物の光二量 化は1,2-1,2付加, 1,2-1,4付加, 1,4-1,4付加のいずれ かで起こり得り，アントラセンは $1,4-1,4$ 付加方式で進 行する。この二量化は酸素の存在により影響を受けない。 (5) 光転位

電子的に励起した分子は，基底状態の分子よりかなり．<smiles></smiles>

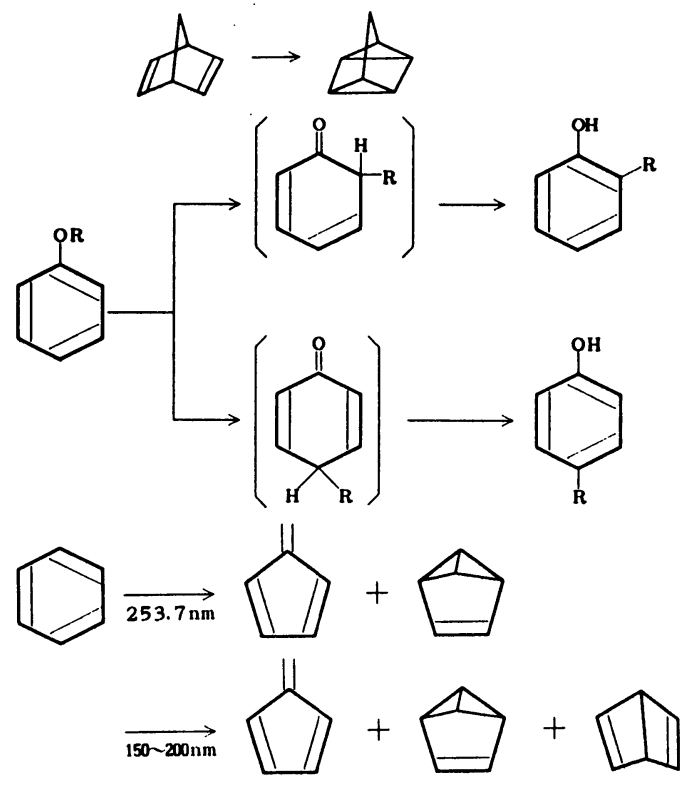

過㮃のエネルギーを有し，分子内で結合系の変化や骨格 を形成する原子の位置の変化が起こり，構造異性体や原 子価異性体を生成することがある。スチルベンの cistrans 異性化やオレフィン化合物の分子内光環化反応, 置換芳香族化合物の光 Fries 転位, ベンゼン環内の転位 などがある。

\section{（6）光分解}

光分解は，環境化学分野では最も関連が深い反応であ ろう。光分解生成物の種類は，その反応が気相で行われ たか, 液相で行われたかに依存することが多い。第一解 離段階 $\mathrm{R}-\mathrm{R}^{\prime} \rightarrow \mathrm{R} \cdot+\mathrm{R}^{\prime} \cdot$ から得られるラジカルはホッ トラジカルであることが多く，気相中では他のラジカル あるいは分子と衝突する前に分子内で反応するが, 溶液 中の場合には“溶媒かご’に囲まれ，反応を起こす前に互 いに衝突して原分子を再生したり，溶媒分子と反応する ことがある。水素を有する溶媒の場合，水素引き抜きが 起こり, $\mathrm{R}-\mathrm{H}$ あるいは $\mathrm{R}^{\prime}-\mathrm{H}$ 型の生成物ができる。以 下，各種化合物の光分解の例を示す。

ハロゲン類の塩素, 臭素, ヨウ素は可視光線でも解離 し，ハロゲンラジカルを生じる。オレフィンの存在下で は連鎖反応が起こる。この付加反応における反応性は, 塩素>臭素>ヨウ素の順に減少する。ハロゲン化水素も 紫外線で解離し，同様な付加反応を行う。

$$
\begin{aligned}
& \mathrm{X}_{2} \rightarrow 2 \mathrm{X} \cdot \\
& \mathrm{X} \cdot+\mathrm{R}_{2} \mathrm{C}=\mathrm{CR}_{2} \rightarrow \mathrm{R}_{2} \mathrm{CXC}_{2} \\
& \mathrm{R}_{2} \mathrm{CX} \dot{\mathrm{CR}}_{2}+\mathrm{X}_{2} \rightarrow \mathrm{R}_{2} \mathrm{CXCXR}_{2}+\mathrm{X} \cdot \\
& \mathrm{HX} \rightarrow \mathrm{H} \cdot+\mathrm{X} \cdot \\
& \mathrm{X} \cdot+\mathrm{RCH}=\mathrm{CH}_{2} \rightarrow \mathrm{R}^{\mathrm{C}} \mathrm{HCH}_{2} \mathrm{X} \\
& \mathrm{R} \dot{\mathrm{C}} \mathrm{HCH}_{2} \mathrm{X}+\mathrm{HX} \rightarrow \mathrm{RCH}_{2} \mathrm{CH}_{2}+\mathrm{X} \cdot
\end{aligned}
$$

第一吸収バンド $(200$ 300nm) の波長の光でハロゲ ン化アルキルを光分解すると $\mathrm{C}-\mathrm{X}$ 結合の切断が起こ る。また，第二吸収バンド $(170 \sim 200 \mathrm{~nm})$ で光分解す ると $\mathrm{HX}$ を脱離する。

$$
\begin{aligned}
& \mathrm{RX}_{200 \sim 300 \mathrm{~nm}} \mathrm{R} \cdot+\mathrm{X} \cdot \\
& \mathrm{RCH}_{2} \mathrm{CH}_{2} \mathrm{X}_{170 \sim 200 \mathrm{~nm}} \mathrm{RCH}=\mathrm{CH}_{2}+\mathrm{HX}
\end{aligned}
$$

芳香族ハロゲン化物を光照射すると，第一段階で C一 X 結合が切断する。

\section{$\mathrm{C}_{6} \mathrm{H}_{5} \mathrm{X} \rightarrow \mathrm{C}_{6} \mathrm{H}_{5} \cdot+\mathrm{X} \cdot$}

パラフィン炭化水素の最低エネルギー吸収は真空紫外 領域 $(120 \sim 200 \mathrm{~nm})$ で分解し難いが, この吸収バンド 内の光を照射すると，主に水素の脱離を起こす。

$$
\mathrm{RCH}_{2} \mathrm{R}^{\prime} \rightarrow \mathrm{RC} \mathrm{R}^{\prime}+\mathrm{H}_{2}
$$

気相中でのオレフィン炭化水素の光分解では, 主に水 素脱離が起こるが, 液相中では異性化のみを起こすこと 
が多い。

芳香族炭化水素は脂肪族炭化水素に比べて光に対して より安定である。気相中, 第一吸収バンド $(253.7 \mathrm{~nm})$ 領域の光でベンゼンを照射しても分解は起こり難いが, 第二，第三吸収バンド $(185 \sim 200 \mathrm{~nm})$ 領域の光を用い るとかなりの分解が起こり, アセチレン, 水素, メタン, エタン及び重合体が生成する。

アルキルベンゼン類の第一吸収バンド領域の光を照射 すると, アルキル基内での結合切断が起こる。

$$
\begin{aligned}
\mathrm{C}_{6} \mathrm{H}_{5} \mathrm{CH}_{2} \mathrm{CH}_{3} & \rightarrow \mathrm{C}_{6} \mathrm{H}_{5} \dot{\mathrm{C}} \mathrm{HCH}_{3}+\mathrm{H} \cdot \\
& \rightarrow \mathrm{C}_{6} \mathrm{H}_{5} \mathrm{CH}=\mathrm{CH}_{2}+\mathrm{H}_{2} \\
& \rightarrow \mathrm{C}_{6} \mathrm{H}_{5} \mathrm{CH}_{2} \cdot+\cdot \mathrm{CH}_{3}
\end{aligned}
$$

脂肪族カルボニル化合物を最長波長吸収バンド $(270$ $\sim 300 \mathrm{~nm}$ ）領域の光で分解すると, カルボニル基の $\alpha$ 結 合の切断と CO の脱離する段階が含まれる Norrish Type I 過程及び $\gamma$ 水素原子がカルボニル基の酸素原子に結合 するような六員環遷移状態が含まれる Norrish Type II 過程を経て生成物が得られる。

$<$ Norrish Type I >

$$
\begin{aligned}
& \mathrm{RCOR}^{\prime} \rightarrow \mathrm{RCO} \cdot+\mathrm{R}^{\prime} \cdot \rightarrow \mathrm{R} \cdot+\mathrm{R}^{\prime} \cdot+\mathrm{CO} \\
& \mathrm{RCOR}^{\prime} \rightarrow \mathrm{R} \cdot+\mathrm{R}^{\prime} \mathrm{CO} \cdot \rightarrow \mathrm{R} \cdot+\mathrm{R}^{\prime} \cdot+\mathrm{CO}
\end{aligned}
$$

環式ケトン類では, カルボニル基の $\alpha$ 結合の開裂によ りビラジカルが生成し, $\mathrm{CO}$ を脱離後, 分解や環化する。 カルボニル化合物からのCO の脱離は気相では容易に起 こるが, 液相では環の張力の程度に影響されるため, 小 あるいは中員環化合物以外は光分解しない。

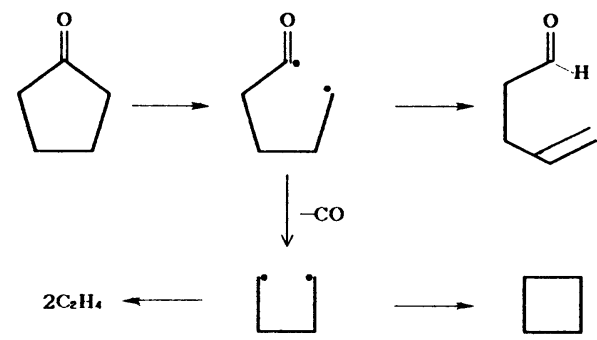

$<$ Norrish Type II >

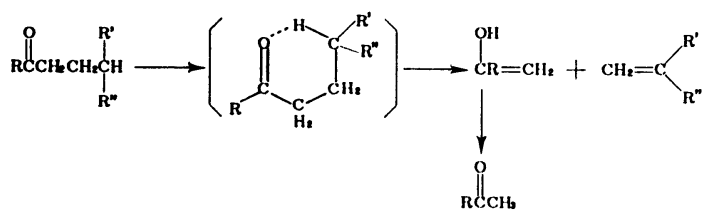

脂肪族酸及びエステルを最長波長吸収バンド内で光照 射すると, 官能基内で結合開裂が起こる。生成したラジ カルが反応して, 炭化水素, オレフィン, $\mathrm{CO}_{2}, \mathrm{CO}$ を 生成する。RCOOR' 型のエステルがRに $\gamma$ 水素あるいは
$R^{\prime}$ に $\beta$ 水素を有していれば, Norrish Type II 過程の反応 が進行する。

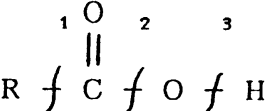
${ }_{11}^{O} \quad 2 \quad 3$
$\mathrm{R}^{\mathrm{C}}$

短波長光 $(<200 \mathrm{~nm})$ による脂肪族アルコール類及び エーテル類の気相光分解では, $\mathrm{C}-\mathrm{O}$ 及び $\mathrm{O}-\mathrm{H}$ 結合の 開裂を起こすが, 液相光分解では気相のような複雑な反 応を起こすことはない。

$$
\begin{aligned}
\mathrm{CH}_{3} \mathrm{CH}_{2} \mathrm{CH}_{2} \mathrm{OH} & \rightarrow \mathrm{CH}_{3} \mathrm{CH}_{2} \mathrm{CH}_{2} \cdot+\mathrm{OH} \cdot \\
& \rightarrow \mathrm{CH}_{3} \mathrm{CH}_{2} \mathrm{CH}_{2} \mathrm{O} \cdot+\mathrm{H} \cdot \\
& \rightarrow \mathrm{CH}_{3} \mathrm{CH}_{2} \mathrm{CHO}+\mathrm{H}_{2} \\
& \rightarrow \mathrm{CH}_{3} \mathrm{CHCH}_{2}+\mathrm{H}_{2} \mathrm{O} \\
& \rightarrow \mathrm{CH}_{3} \mathrm{CH}_{3}+\mathrm{CH}_{2} \mathrm{O}
\end{aligned}
$$

アルキルペルオキシドは第一吸収バンド（200 $350 \mathrm{~nm})$ の光を吸収して, 弱い RO - OR' 結合位で開裂 する。230nm 以下の波長光を用いると第二の解離段階が 重要となる。

$$
\mathrm{RO}-\mathrm{OR}^{\prime} \rightarrow \mathrm{RO}^{*} \cdot+\cdot \mathrm{OR}^{*}
$$

$\mathrm{ROOR}^{\prime} \rightarrow \mathrm{RO}_{2}^{*} \cdot+\mathrm{R}^{\prime}$.

アルキル亜硝酸エステル類の主な光分解過程は, RO -NO 結合の解離である。

$\mathrm{RO}-\mathrm{NO} \rightarrow \mathrm{RO} \cdot+\mathrm{NO} \cdot$

脂肪族アミドは200～230nm の波長領域の光で分解す ると，C-N あるいは $\mathrm{C}-\mathrm{C}$ 結合の切断が起こる。

$$
\begin{aligned}
\mathrm{RCONH}_{2} & \rightarrow \mathrm{RCO} \cdot+\cdot \mathrm{NH}_{2} \\
& \rightarrow \mathrm{R} \cdot+\cdot \mathrm{CONH}_{2}
\end{aligned}
$$

脂肪族第一アミンの主な光分解過程は, $\mathrm{N}-\mathrm{H}$ 結合の 切断とアミノ基の $\alpha$ 位の $\mathrm{C}-\mathrm{H}$ 結合の切断である。

$$
\begin{aligned}
\mathrm{RCH}_{2} \mathrm{NH}_{2} & \rightarrow \mathrm{RCH}_{2} \dot{\mathrm{N} H}+\mathrm{H} \cdot \\
& \rightarrow \mathrm{RC}^{\mathrm{C}} \mathrm{HNH}_{2}+\mathrm{H} \cdot
\end{aligned}
$$

芳香族化合物は発光過程を経てエネルギーを失うこと ができるので, 脂肪族アミンよりも安定である。しかし, 芳香族アミン類の光解離はある程度起こっている。

$$
\begin{aligned}
\mathrm{C}_{6} \mathrm{H}_{5} \mathrm{NH}_{2} & \rightarrow \mathrm{C}_{6} \mathrm{H}_{5} \mathrm{NH} \cdot+\mathrm{H} \cdot \\
& \rightarrow \mathrm{C}_{6} \mathrm{H}_{5} \cdot+\cdot \mathrm{NH}_{2}
\end{aligned}
$$

アゾアルカンは気相では容易に分解するが，液相では 異性化が優先する。

$$
\text { trans } \begin{aligned}
\mathrm{CH}_{3}-\mathrm{N}=\mathrm{N}- & \mathrm{CH}_{3} \rightarrow 2 \mathrm{CH}_{3} \cdot+\mathrm{N}_{2} \\
& \rightarrow \text { cis } \mathrm{CH}_{3}-\mathrm{N}=\mathrm{N}-\mathrm{CH}_{3}
\end{aligned}
$$


ジアゾ化合物及び脂肪族アジド類は次のように分解す

る。

$$
\begin{aligned}
& \mathrm{CH}_{2} \mathrm{~N}_{2} \rightarrow \mathrm{CH}_{2}+\mathrm{N}_{2} \\
& \mathrm{R}-\mathrm{N}=\overline{\mathrm{N}}=\stackrel{+}{\mathrm{N}} \rightarrow \mathrm{R}-\mathrm{N}:+\mathrm{N}_{2}
\end{aligned}
$$

\section{4. 環境化学分野における最近の光化学反 応実赜例}

最後に, 環境化学分野における光化学反応に係わる最 近の研究報告例を紹介する。

大気関係の報告は多く, オゾンや過酸化水素, $\mathrm{NO}_{\mathrm{x}}$, $\mathrm{SO}_{\mathrm{x}}, \mathrm{PAN}$ に関するものが目立つ。Shu ら ${ }^{12)}$ はテフロン スモッグチャンバーを用いて, 多環芳香族炭化水素類の 一次分解速度定数を求めており, 速度定数は光強度や水 蒸気濃度に比例し, 多環芳香族炭化水素類の半隇期は冬 期で数日間，夏期で数時間であることを報告している。 Derwent $ら^{13)}$ は69種類の炭化水素類を対象として, オゾ ンやPANの生成について調べており，Zhang ら ${ }^{14)}$ はキ セノンランプを用いて, 空気, 酸素, 窒素中でのシリカ ゲル表面上の1-ニトロピレンの分解速度や生成物につい て調ベ，ピレンキノンが主生成物で，その他ポリニトロ ヒドロキシピレンが検出されたことを報告している。ま た, 大内ら ${ }^{15)}$ は粒子状物質へのフロン11の吸脱着にお ける光や水の影響について調べている。 $\mathrm{NO}_{\mathrm{x}}$ との反応に ついては, Pandis $~^{16)}$ が生物由来の物質であるイソプ レン, $\beta$-ピネンについて, Sakamoto ら ${ }^{17)}$ がシクロヘキ センについて, Lai $~^{18)}$ が肺胞表面活性㓮成分の $\beta$-才 レオイルー $\gamma$ パルミトイル L- $\alpha$-ホスファチジルコリン について, $\operatorname{Cox} ら^{19)}$ がメタン, イソブテン, ベンゼン等 の揮発性物質について報告している。その他, アルミニ ウムポリフィリン錯体を用いた大気中の $\mathrm{CO}_{2}$ の除去に 関する報告 ${ }^{20)}$ も見られる。

水関係では, 水環境中での挙動や水処理, 脱色, 殺菌 等についての報告が見られる。著者らは低圧及び高圧水 銀ランプを用いて, 数十種類の芳香族有機塩素化合物 $5,6,11)$ と 7 種類の有機リン酸エステル類 ${ }^{7,21)}$ の分解挙動 並びに生成物を同定している。白山ら ${ }^{22)}$ はトリクロロ エチレン，テトラクロロエチレン，1１１１-トリクロロエ タンの紫外線照射による分解速度と曝気拡散方式による 除去速度を比較しており, Akhlaq ${ }^{23)}$ は藻類由来のポ リウロン酸のモデル物質として多糖類アルギン酸につい て, Guittonneau ら ${ }^{24)}$ はオゾンの過酸化水素への紫外線 による分解性について研究している。また, ベンゼンス ルホン酸25,26)やフミン酸 ${ }^{27)}$, フェノール ${ }^{28)}$, クロロニ トロベンゼン類 ${ }^{29)}, \mathrm{p}$-ニトロフェノール, m-アミノフェ

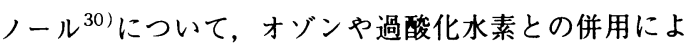
る分解挙動についての報告や硝酸イオン, 覀硝酸イオン

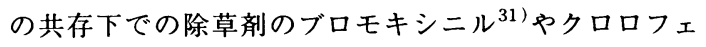

ノール類 ${ }^{32)}$ の分解生成物についての報告も見られる。 Hawari ${ }^{33)}$ はメチルアルコールー水混合溶液中, $\mathrm{CH}_{3} \mathrm{SiO}_{2} \mathrm{Na}_{3}$ の存在下で紫外線を照射し, 4-クロロビフェ ニル及びAroclor 1254 の分解性について調べており， Lipczynska-Kochany $ら^{34)}$ は過酸化水素-Fenton 試薬存在 下で4-ニトロフェノールの分解性を調べている。

金属に関しても報告が見られ, Helz ら ${ }^{35)}$ は太陽光に よるクロム（VI）の光還元反応について, Fukasawa ら 36)は $1 \mathrm{M}$ 硝酸中, 尿素, $\mathrm{Pt}-\mathrm{TiO}_{2}$ あるいはヒドラジン, $\mathrm{Pt}-\mathrm{SiC}$ 存在下でネプッニウム $(\mathrm{V})$ の光酸化還元反応 について調べている。

McCloskey ${ }^{37)}$ はアントラセン水溶液に疑似太陽光を 当て, $\mathrm{LC}_{50}$ と溶存酸素との関係を求めており, Kagan $ら^{38)}$ は $\alpha$-ter-チエニルに近紫外線を照射した溶液が強 い魚毒性を示すことを報告している。

実試料を用いた水処理実験については, Lewis $ら^{39) か ゙ ~}$ 揮発性有機化合物に污染された地下水について, オゾン や過酸化水素を併用した紫外線照射による処理を行って おり，Wekhof ${ }^{40)}$ がキセノンフラッシュランプを用いて， トリクロロエチレン及び芳香族縮合化合物に污染された 水, 土壤及び空気の処理を行っている。下水の処理水に ついては，大瀧ら ${ }^{41)}$ が塩素を併用した紫外線照射によ るCOD の削減やクロラミンの分解について調べている。 その他, オゾンや過酸化水素を併用しての漂白廃水中の 有機ハロゲン化合物の処理 ${ }^{42)}$ や PCB を使用している蓄 電器の事故によるダイオキシン污染対策 ${ }^{43)}$ の報告があ る。

紫外線による脱色も行われており，市川ら ${ }^{44)}$ はアソ 染料のオゾン, 過酸化水素併用紫外線照射による窒素の 挙動について, Matthews ${ }^{45)}$ は酸化チタン, 過酸化水素 存在下での中圧水銀ランプや太陽光によるメチレンブ

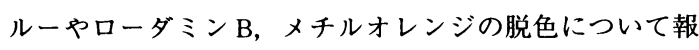
告している。

紫外線による殺菌に関しては, Wolfe ${ }^{46)}$ が地下水につ いて, 堺ら ${ }^{47)}$, 中村 ${ }^{48)}$ が下水処理水中の大腸菌の不活 性化について行っている。

その他, フローインジェクション方式の水中リンの分 析法で酸化分解に紫外線を用いたり ${ }^{49)}$ ，アオコ対策に 紫外線照射法を用いた ${ }^{50}$ 報告がある。

\section{5. おわりに}

人類初期の物質への作用手段は, 切る壊す等の物理的 力によっていたが，その後燃焼や薬剤による化学的手段 が用いられ，近年では紫外線，赤外線，放射線等の電磁 波を各分野で用いるようになった。物質は原子や分子間 の振動でその状態を維持しているが，ある振動数以上の 電磁波を与えれば切断が選択的に, 効率良く, 各部分で 同時に起こり得るので，化学物質を含む用・廃水処理や 
廃ガス処理等における分子レベルでの破壊には好都合で ある。また，薬剤使用のように未反応の薬剤や薬剤の分 解物, 薬剤との反応生成物の心配もなく, 環境分野に応 用していく上での利点もある。物質と電磁波の反応は水 圈や大気圈でも起こっており，環境化学分野に電磁波を 用いるのは理にかなった方法とも言える。しかし，実用 化して行くには分解補助剤の添加や経済性，反応生成物 の毒性等の問題も残されており，今後の研究成果に期待 したい。その点, キャピラリーカラム $-\mathrm{GC} / \mathrm{MS}$ や HPLC / MS などの最近の分析技術の発達は, 光化学反応 機構を解明して行く上で大いに貢献するものと考える。

\section{文 献}

1）松浦輝男：「有機光化学」, 化学同人, 京都, (1974)

2) Alberty, R.A. :「アルバーティ物理化学(下)」, 妹 尾学他訳, 東京化学同人, 東京, (1991)

3) Streitwieser, A.：「ストライトウィーザー有機化学 解説 2$\lrcorner$, 湯川泰秀監訳, 廣川書店, 東京, (1992)

4) Morrison, R.T. and Boyd, R.N. : 「モリソン・ボイド 有機化学(上), 第 4 版」, 中西香爾他訳, 東京化学 同人，東京，(1985)

5）石川精一，末田新太郎，城戸浩三：低圧水銀ランプ を用いた有機塩素化合物の水中における光分解性. 第22回水質污濁学会講演集, pp 375-376,（1988）

6) Ishikawa, S., Baba, K., Hanada, Y., Uchimura, Y. and Kido, K.: Photodecomposition of o-chloroaniline in aqueous solution with low pressure mercury lamp. Bull. Environ. Contam. Toxicol., 42, 65-70, (1989)

7) Ishikawa, S., Uchimura, Y., Baba, K., Eguchi, Y. and Kido, K.: Photochemical behavior of organic phosphate esters in aqueous solutions irradiated with a mercury lamp. Bull. Environ. Contam. Toxicol., 49, 368-374, (1992)

8) 斎藤 烈: 有機光化学反応の研究の進め方, pp 2615-2629, 「新実験化学講座14」, 高橋武美編集, 丸善, 東京, (1978)

9) Wells, C.H.J. : 「有機光化学序論」, 東京化学同人, 東京, (1977)

10）安藤 亘：「有機合成における光化学反応」, 三共 出版, 東京, (1983)

11）石川精一，末田新太郎：有機塩素化合物の水中にお ける光分解性, 第 21 回水質污濁学会講演集, pp 201-202, (1987)

12) Shu, Y., Li, J. and Wang, W.: The study for polyaromatic hydrocarbons decay on Chinese coal soot particles in atmosphere. J. Environ. Sci., 3, 71-80, (1991)

13) Derwent, R.G. and Jenkin, M.E.: Hydrocarbons and the long-range transport of ozone and PAN across Europe. Atom. Environ. Part A, 25, 1661-1678, (1991)

14) Zhang, Z., Jin, Z., Zhu, N. and Xu, X.: Photochemical reaction of particle-bond 1-nitropyrene under simulated atmospheric condition. J. Environ. Sci., 1, 15-22, (1989)

15）大内日出夫, 指宿克嗣, 竹内浩士, 忽那周三 : 不活 性化学物質の不均一系光反応による変換・分解に関 する研究. 環境保全研究成果集 1, pp 42.1-42.16, (1988)

16) Pandis, S.N., Paulson, S.E., Baltensperger, U., Seinfeld, J.H., Flagan, R.C., Palen, E.J. and Allen, D.T.: Biogenic hydrocarbons as aerosol precursors, an outdoor smog chamber study. Aerosols, 2, 974-977, (1990)

17) Sakamoto, K., Nakajima, M., Otsuka, S., Iwamoto, I. and Yamaki, N.: Strong dependence of aerosol organic carbon yield on the initial hydrocarbon/ nitrogen oxides concentration ratio in the photochemical reaction of cyclohexene- $\mathrm{NO}_{\mathrm{x}}$-air system. Chem. Express, 5, 921-924, (1990)

18) Lai, C.C. and Finlayson-Pitts, B.J.: Reactions of oxidant air pollutants with model compounds for pulmonary surfactant. Am. Chem. Soc. Natl. Meet Div. Environ. Chem., 30, 50-52, (1990)

19) Cox, R.A.: Chemical ractivity in the troposphere as applied to organic molecules. Atmos., 33, 9-18, (1991)

20) 井上祥平：いま問題の $\mathrm{CO}_{2}$ を考える, $\mathrm{CO}_{2}$ の化学的 固定最前線, $\mathrm{CO}_{2}$ の光化学的固定, 化学, 46, 310-312, (1991)

21）石川精一, 重住研一, 安田和彦, 重森伸康：有機リ ン酸エステル類の各種水処理過程における挙動. 水 質污濁研究，8，799-807，(1985）

22）白山 肇, 安念 清, 坂森重治: 有機塩素化合物の 分解に関する研究(第 1 報), 紫外線照射によるテト ラクロロエチレン等の光分解. 富山県公害センター 年報, 19, 141-150，（1991）

23) Akhlaq, M.S., Schuchmann, H.-P. and Von Sonntag, C.: Degradation of the polysaccharide alginic acid, A comparison of the effects of UV light and ozone. Environ. Sci. Technol., 24, 379-383, (1990)

24) Guittonneau, S., De Laat, J. and Dore, M.: Etude cinetique de la photodecomposition del'ozone en solution aqueuse par irradiation U.V. a $253.7 \mathrm{~nm}$. Environ. Technol. Lett., 11, 477-490, (1990)

25）松本久男, 村上和也：アルキルベンゼンスルホン酸 
塩のUV照射とオゾン処理による分解(第 2 報), ベ ンゼンスルホン酸の分解生成物. 第23回水質污濁学 会講演集, pp 31-32,（1989）

26）村上和也, 松本久男：アルキルベンゼンスルホン酸 塩のUV照射とオゾン処理による分解, 第 2 報, ベ ンゼンスルホン酸の分解生成物. 衛生化学, 36 , 62-68, (1990)

27) Kusakabe, K., Aso, S., Hayashi, J.-I., Isomura, K. and Morooka, S.: Decomposition of humic acid and reduction of trihalomethane formation potential in water by ozone with u.v. irradiation. Water Res., 24, 781-785, (1990)

28) Takahashi, N.: Ozonation of several organic compounds having low molecular weight under ultraviolet irradiation. Ozone, 12, 1-17, (1990)

29) Guittonneau, S., De Laat, J., Dore, M., Duguet, J.P. and Bonnel, $\mathrm{C}$.: Oxidation of parachloronitrobenzene in dilute aqueous solution by $\mathrm{O}_{3}+\mathrm{UV}$ and $\mathrm{H}_{2} \mathrm{O}_{2}+$ UV, comparative study. Ozone, 12, 73-93，(1990)

30）市川広保, 和田真二, 辰巳憲司：化学酸化法による フェノール類の酸化分解. 工業用水, 401，26-32, (1992)

31) Kochany, J.: Photochemistry of halogenated benzene derivatives. Toxicol. Environ. Chem., 27, 225-239, (1990)

32) Schedel, G., Lenoir, D. and Boule, P.: Phototransformation of monochlorophenols induced by excitation of nitrate ions. Chemosphere, 22, 1063-1069, (1991)

33) Hawari, J., Demeter, A., Samson, R., Tronczynski, J. and Mourato, D.: Photodechlorination of chlorobiphenyls by sodium methyl siliconate. Chemosphere, 22, 189-199, (1991)

34) Lipczynska-Kochany, E.: Novel method for a photocatalytic degradation of 4-nitrophenol in homogeneous aqueous solution. Environ. Technol., 12, 87-92, (1991)

35) Helz, G.R. and Kieber, R.J.: The role of photochemistry in the bioavailability of toxic substances in estuaries, implications for monitoring. PB Rep., PB-89-207484, 449, (1988)

36) Fukasawa, T., Takahashi, M., Ikeda, T. and Kawamura, F.: Photochemical redox behaviors of neptunium in nitric acid solution. Proc. RECOD 91, 2, 803-808, (1991)

37) McCloskey, J.T. and Oris, J.T.: Effect of water temperature and dissolved oxygen concentration on the photo-induced toxicity of anthracene to juvenile bluegill sunfish. Aquatic Toxicol., 21, 145-156, (1991)

38) Kagan, J., Stephens, N., Kulakkattolickal, A. T. and Wang, T.P.: Variables affecting the phototoxicity of $\alpha$-terthienyl toward fish in the laboratory. Chemosphere, 22, 699-703, (1991)

39) Lewis, N., Topudurti, K., Welshans, G. and Foster, R.: A field demonstration of the UV / Oxidation technology to treat ground water contaminated with VOCs. J. Air Waste Manage. Assoc., 40, 540-547, (1990)

40) Wekhof, A.: Treatment of contaminated water, air and soil with UV flashlamps. Environ. Prog., 10, 241-247, (1991)

41）大瀧雅寛, 大垣真一郎：下水処理における紫外線照 射と塩素注入との併用処理. 土木学会年次学術講演 会講演概要集，第 2 部，45th，900-901，(1990)

42) Smith, P.W.: AOX reduction in bleach plant effluent using enhanced oxidation. TAPPI Proc. Environ. Conf., 1990, Book 2, 769-772, (1990)

43) Borwitzky, H. and Schramm, K.-W.: Reduction of dioxin concentrations on contaminated surfaces. Chemosphere, 22, 485-493, (1991)

44）市川広保, 和田慎二, 辰巳憲司：アゾ染料を過酸化 水素添加紫外線照射法により酸化したときの窒素の 挙動. 公害, 25, 145-153，（1990）

45) Matthews, R.W.: Photooxidative degradation of coloured organics in water using supported catalysts, $\mathrm{TiO}_{2}$ on sand. Water Res., 25, 1169-1176, (1991)

46) Wolfe, R.L.: Ultraviolet disinfection of potable water. Environ. Sci. Technol., 24, 768-773, (1990)

47）堺 好雄, 中尾彰夫, 布施達夫:下水二次処理水の 紫外線消毒. 下水道研究発表会講演集, $27 \mathrm{th}$, 423-425, (1990)

48）中村宗一郎：塩素, オゾン及び紫外線処理による懸 濁粒子化した䔬便性大腸菌群不活化の定量化. 下水 道協会誌，28，40-46，（1991）

49) Mckelvie, I.D., Hart, B.T., Cardwell, T.J. and Cattrall, R.W.: Spectrophotometric determination of dissolved organic phosphorus in natural waters using in-line photo-oxidation and flow injection. Analyst, 114, 1459-1463, (1989)

50）佐々木吉彦：紫外線による水質浄化. 建設電気技術, 96, 50-57, (1992) 